\title{
Posterior reversible encephalopathy syndrome in association with exacerbation of chronic obstructive pulmonary disease: a case report
}

Sushil Khanal ${ }^{*}$ iD and Subhash Prasad Acharya

\begin{abstract}
Background: Posterior reversible encephalopathy syndrome (PRES) is a reversible clinical and neurological entity. There are varieties of comorbid conditions which are associated with PRES. Chronic obstructive pulmonary disease (COPD) is a rare predisposing factor for the development of PRES.

Case presentation: A 55 year old female who was being treated for acute exacerbation of COPD developed altered sensorium and multiple episodes of seizure. Characteristic imaging findings and associated clinical symptoms led us to a diagnosis of PRES in our patient.
\end{abstract}

Conclusion: Association of PRES and COPD is a rare entity. The diagnosis of PRES should be brought to mind if there is encephalopathy or seizure in COPD exacerbation.

Keywords: Chronic obstructive pulmonary disease, Posterior reversible encephalopathy syndrome, Encephalopathy, Seizure

\section{Background}

Posterior Reversible Encephalopathy Syndrome (PRES) is characterized by headache, seizure, altered mental status and visual disturbances. It is a clinical and radiological entity and typically causes reversible changes in the posterior circulation system of the brain [1]. The association of PRES has been described frequently with number of medical conditions like hypertensive encephalopathy, eclampsia, and the use of cytotoxic and immunosuppressant drugs [2]. To the best of our knowledge, there are few case reports of PRES in the background of Chronic obstructive pulmonary disease (COPD). Here, we present a case of a 55 year old female with COPD exacerbation developing the characteristics features of PRES.

\section{Case presentation}

A 55 year old female patient was being treated at local hospital for 3 days symptoms suggestive of acute exacerbation

* Correspondence: khanaliom@gmail.com

Department of Critical Care, Grande International Hospital (GIH), Kathmandu, Nepal

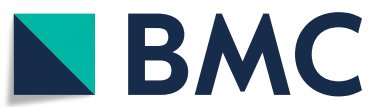

of COPD. She was referred to our center for further management after she developed multiple episodes of seizure followed by loss of consciousness on the first day of hospital admission. The patient's relatives revealed that she had history of COPD for last 5 years but was not compliant to inhaler medications. Her family history was unremarkable. She has been a smoker for the last 30 years. No other significant history was available.

On examination, the patient was drowsy, and was not obeying commands. She had a temperature of $37.6^{\circ} \mathrm{C}$, blood pressure of $130 / 80 \mathrm{mmHg}$, pulse rate of $96 / \mathrm{min}$ and respiratory rate of $26 / \mathrm{min}$. She had widespread expiratory wheeze. While the patient was regaining consciousness, she reported of headache and a decreased vision. An ocular examination revealed normally reactive pupil and fundus. Cranial nerves examination was unremarkable. Motor and sensory function examination was normal. There was no any clinical sign of meningeal irritation.

Her laboratory tests on admission were as follows: hemoglobin, $17 \mathrm{~g} / \mathrm{dl}$; white blood cells, 12640 /Cumm; platelets, 155000 /Cumm; urea, $37 \mathrm{mg} / \mathrm{dl}$; creatinine

(C) The Author(s). 2018 Open Access This article is distributed under the terms of the Creative Commons Attribution 4.0 International License (http://creativecommons.org/licenses/by/4.0/), which permits unrestricted use, distribution, and reproduction in any medium, provided you give appropriate credit to the original author(s) and the source, provide a link to the Creative Commons license, and indicate if changes were made. The Creative Commons Public Domain Dedication waiver (http://creativecommons.org/publicdomain/zero/1.0/) applies to the data made available in this article, unless otherwise stated. 


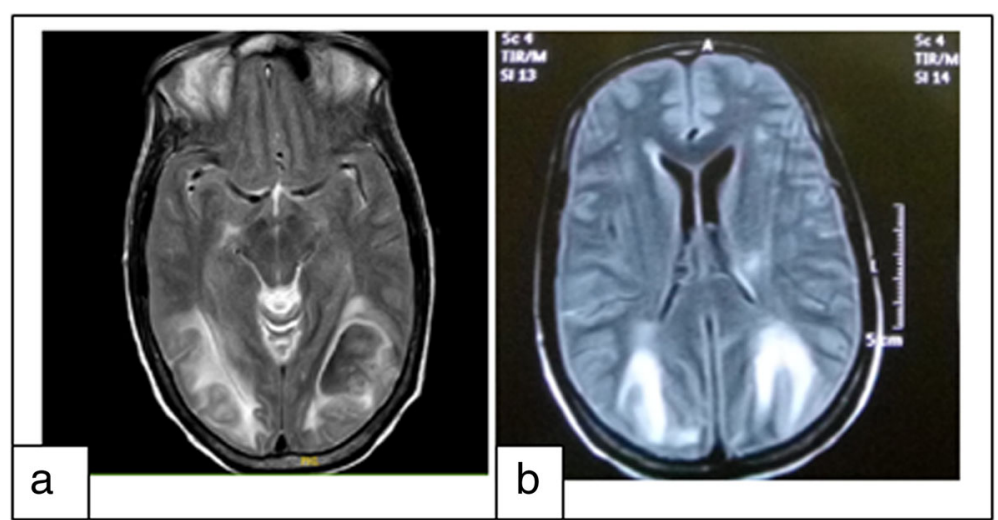

Fig. 1 MRI findings (T2 sequence (a), FLAIR (b)) showing the diffuse confluent white matter hyperintensities in bilateral parieto- occipital region

$0.3 \mathrm{mg} / \mathrm{dl} ; \mathrm{Na}, 132 \mathrm{meq} / \mathrm{L} ; \mathrm{K}, 4.6 \mathrm{meq} / \mathrm{L}$. Chest $\mathrm{X}$-radiography revealed emphysematous changes. Arterial blood gas finding showed the $\mathrm{pH}, 7.56 ; \mathrm{pCO}_{2}, 46.2 ; \mathrm{pO}_{2}$, 81.0; $\mathrm{HCO}_{3}, 41.5$. Magnetic Resonance Imaging (MRI) demonstrated hyperintense lesions in the bilateral parietooccipital region consistent with PRES (Fig.1).

Our patient was treated with salbutamol and ipratropium nebulisation, hydrocortisone, levetiracetam and other supportive care. The patient was continuously monitored for hemodynamic stability in Intensive Care Unit (ICU) for 2 days and was later transferred to a general ward. The patient continued to improve clinically and was discharged home on the sixth day of hospitalization without any respiratory and neurological symptom.

\section{Discussion and conclusion}

Posterior reversible encephalopathy syndrome (PRES) has been described as a clinical syndrome of headache, altered level of consciousness, visual changes, and seizure. There is a characteristic neuroimaging finding of posterior cerebral white matter edema in PRES. Although pathogenesis of PRES is unclear, it is likely to be the consequences of disordered cerebral autoregulation and endothelial dysfunction [1].

A variety of clinical conditions like hypertensive emergency, renal disease, pre-eclampsia/eclampsia and use of immunosuppressive agents are commonly associated with the development of PRES. There are very few case reports linking the relation of PRES with COPD [3, 4]. Increased level of circulating tumor necrosis factor alpha (TNF $\alpha$ ), interleukin-1 (IL-1) and endothelin-1 (ET-1) in COPD causes endothelial dysfunction in cerebral arteries. Infection during COPD exacerbation also raises the levels of IL-1, TNF $\alpha$ and ET-1. This may be the most probable pathophysiology behind the development of PRES during COPD exacerbation [4].

Differential diagnosis of PRES include other neurologic conditions, such as stroke, venous thrombosis, toxic or metabolic encephalopathy, demyelinating disorders, vasculitis, or encephalitis. As there is limited history and broad differential diagnosis, early neuroimaging is crucial for the diagnosis of PRES [5]. Typical MRI findings in PRES are of bilateral white-matter abnormalities in vascular watershed areas in the posterior regions of both cerebral hemispheres, affecting mostly the occipital and parietal lobes [6].

The predilection of posterior brain regions in PRES is not well understood. One possibility involves the regional heterogeneity of the sympathetic innervation of the intracranial arterioles, with better development of sympathetic autoregulation in the anterior circulation than in the posterior circulation [7]. Removal of precipitating factors seem to enhance the full recovery of PRES within a period of days to weeks in most of the cases. However, radiologic improvement lags behind clinical recovery $[8,9]$.

In Conclusion, there is high rate of admission of COPD in the Intensive Care unit. Although the association of COPD and PRES is rare entity, the differential diagnosis of PRES should be kept in the mind whenever there is encephalopathy or seizure in COPD exacerbation.

\section{Abbreviations \\ COPD: Chronic obstructive pulmonary disease; ET-1: Endothelin-1; \\ ICU: Intensive care unit; IL-1: Interleukin-1; MRI: Magnetic resonance imaging; PRES: Posterior reversible encephalopathy syndrome; TNFa: Tumor necrosis factor alpha}

\section{Acknowledgements}

The authors thank Department of Critical Care (Grande International Hospital, Kathmandu).

Ethical approval and consent to participate Not Applicable

Funding

Not Applicable

Availability of data and materials

All the relevant data in the current study will be freely available to any scientist wishing to use them without breaching participant confidentiality for non-commercial purposes. 


\section{Authors' contributions}

Both authors read and approved the final manuscript.

\section{Consent for publication}

Written informed consent was obtained from the patient for publication of this Case Report and any accompanying images.

\section{Competing interests}

The authors declare that they have no competing interests.

\section{Publisher's Note}

Springer Nature remains neutral with regard to jurisdictional claims in published maps and institutional affiliations.

Received: 10 October 2017 Accepted: 24 October 2018

Published online: 31 October 2018

\section{References}

1. Hinchey J, Chaves C, Appignani B, Breen J, Pao L, Wang A, et al. A reversible posterior leukoencephalopathy syndrome. N Engl J Med. 1996;334:494-500.

2. Chambers KA, Cain TW. Postpartum blindness: two cases. Ann Emerg Med. 2004:43:243-6.

3. Tanaka H, Yamamoto D, Uchiyama T, Ohashi T. Posterior reversible encephalopathy syndrome in a woman with chronic obstructive pulmonary disease. Intern Med. 2017;56(9):1119-20.

4. Dardis C, Craciun R, Schell R. Posterior reversible encephalopathy syndrome in the setting of COPD:proposed pathogenesis. Med Hypotheses. 2013;80:197-200.

5. Ay H, Buonanno FS, Schaefer PW, Le DA, Wang B, Gonzalez RG, Koroshetz WJ. Posterior leukoencephalopathy without severe hypertension: utility of diffusion-weighted MRI. Neurology. 1998;51:1369-76.

6. Bartynski W. Posterior reversible encephalopathy syndrome, part 1: fundamental imaging and clinical features. AJNR Am J Neuroradiol. 2008;29:1036-42.

7. Beausang-Linder M, Bill A. Cerebral circulation in acute arterial hypertensionprotective effects of sympathetic nervous activity. Acta Physiol Scand. 1981; 111(2):193.

8. Lee VH, Wijdicks EF, Manno EM, Rabinstein AA. Clinical spectrum of reversible posterior leukoencephalopathy syndrome. Arch Neurol. 2008; 65(2):205.

9. Roth C, Ferbert A. Posterior reversible encephalopathy syndrome: long-term follow-up. J Neurol Neurosurg Psychiatry. 2010;81(7):773.

Ready to submit your research? Choose BMC and benefit from:

- fast, convenient online submission

- thorough peer review by experienced researchers in your field

- rapid publication on acceptance

- support for research data, including large and complex data types

- gold Open Access which fosters wider collaboration and increased citations

- maximum visibility for your research: over $100 \mathrm{M}$ website views per year

At BMC, research is always in progress.

Learn more biomedcentral.com/submissions 